\title{
Analysis Of Satisfaction and Priority Levels of Jaya Makmur Road Development in Supporting Kurik District as A Rice Surplus Area
}

\author{
Muh Akbar, Dina Limbong Pamuttu, Daud Andang Pasalli, and Hairullah Hairullah \\ Department of Civil Engineering, Faculty of Engineering, Musamus University, Merauke 99600, Indonesia
}

\begin{abstract}
Merauke Regency as a national food place is anticipated to create 5.2 million tons of rice each year, identical to 5.41 percent of public rice creation in Indonesian and 88.92 percent of all Papua region. Kurik District is in the second position in Merauke Regency as the largest rice surplus area with a productivity of $47,376.15$ tons or equivalent with 27.41 percent. The inadequate condition of road infrastructure resulted uneasy mobility in agriculture between regions. Finding the level of satisfaction between road performance and community expectations of road construction can be done using the Importance Performance Analysis (IPA) method. Meanwhile, the method used in determining road development priorities is the Analytical Hierarchy Process (AHP). The results of the level of road satisfaction found a gap between road performance and community expectations, namely the need for performance development (quadrant I). While the hierarchical process obtained the priority for the development of the Jaya Makmur Village road is Main Road in Jaya Makmur Village with an eigenvector value of 2.73. This is because Main Road in Jaya Makmur is the main road of Jaya Makmur Village with a condition of 53.19 percent of which is a road with ground level.
\end{abstract}

Keywords: Level Road satisfaction, road network development, national food storage

\section{Preliminary}

Merauke Regency is the largest rice producer in Papua Province. In 2019, rice production in Merauke Regency was $327,877.71$ tonnes. With a rice field area of $58,874.25$ hectares. Kurik District is the second-largest rice producer in Merauke Regency with a harvest area of 17,247 hectares and a production of 100,722 tons [1]. Jaya Makmur Village is one of the villages in Kurik District with an area of $14 \mathrm{~km}^{2}$.

1.2 million hectares of non-conservation peatlands and forests in Merauke Regency are known to have the potential to become productive rice fields. The land has relatively flat contours, allowing for agricultural mechanization. Ir. Joko widodo as the president of the Republic of Indonesia in his speech declared Merauke Regency to be a "national food barn" or a national foodproducing center. With this land area, it is predicted that the production of 5.2 million tons of rice per year, equivalent to 5.41 percent of the national rice production, 88.92 percent of the total province of Papua, or 76.24 percent of the total production on the island of Papua.[2, 3].

National food storage cannot be realized if the development of transportation infrastructure in the Merauke Regency continues to be constrained. In 2015, the length of roads in Merauke Regency reached
$1,820,211 \mathrm{~km}$. The length of the paved road is less than the unpaved road with the percentage reaching 38.63 percent compared to 61.37 percent[4].

The inadequate condition of transportation infrastructure results in a smooth distribution of logistics [5]. Limited development budgets and expensive maintenance of transportation networks require a change in human mindset and strategy towards planning and setting priorities for development effectively, according to generation patterns and movement of movement between regions that are formed in a regional transportation arrangement.[6, 7]. Improved transportation infrastructure and accessibility can improve basic community services in improving the quality of life. The need for an efficient, effective transportation system and delivery time that is following the schedule is the purpose of transportation planning in the logistics system[8-10].

\section{Methodology}

This study uses qualitative methods in the form of questionnaires and quantitative methods by calculating the value of the questionnaire results. The measurement of road network development priority used 50 samples.

\footnotetext{
* Corresponding author : akabr@unmus.ac.id
} 
This method uses Importance Performance Analysis (IPA) to determine the gap between expectations and road network performance. The method used in determining the priority of road development is the Analytical Hierarchy Process (AHP) method.

AHP is a multi-criteria decision-making method for solving complex problems with many variables that can be developed in the development of alternative road network development infrastructure [11-14].

The research location is in Kurik District, Jaya Makmur Village

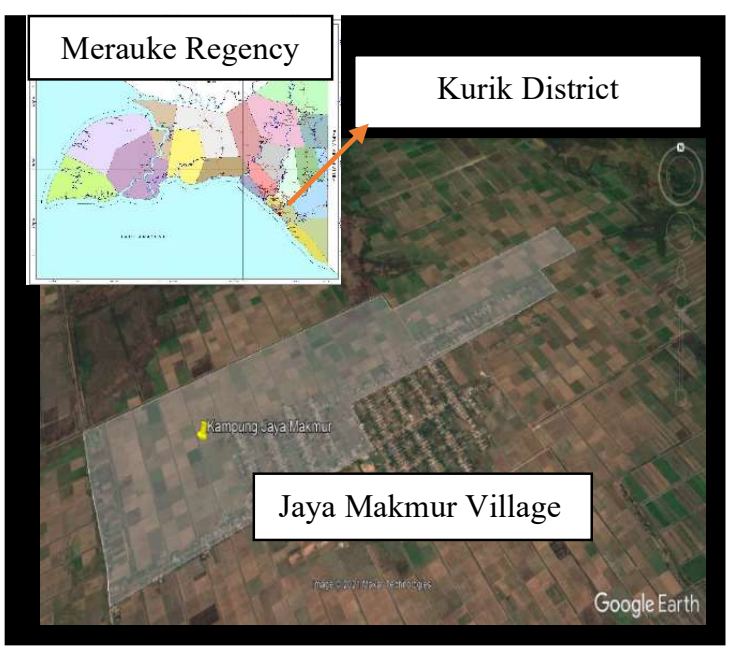

Fig. 1. Jaya Makmur Village, Kurik District.

The following is a model for road development priority policymaking:

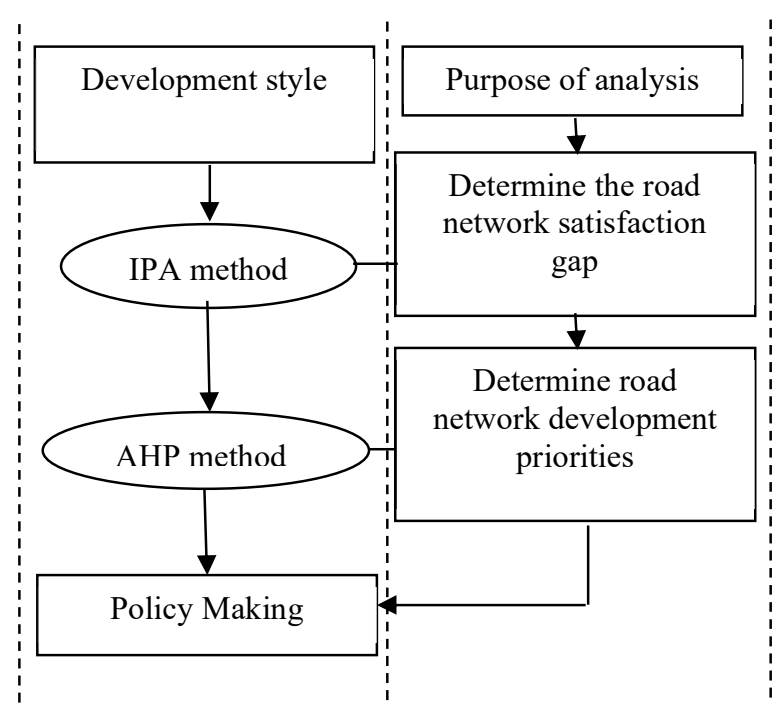

Fig. 2. Chart of road development priorities using the IPA and AHP methods.

\section{Results and Discussion}

\subsection{Captions/numbering}

Production of rice commodities and differences in population numbers in each district make food needs unbalanced so that some districts experiencing a surplus and some other districts experiencing a Deficit. The unequal amount of production makes the need for a logistics transportation network very necessary to reduce disparities between regions.

Table 1. Font styles for a reference.

\begin{tabular}{|c|c|c|}
\hline District Name & Surplus (ton) & $\begin{array}{c}\text { Deficit } \\
\text { (ton) }\end{array}$ \\
\hline Kimaam & & -138.41 \\
\hline Waan & & -213.71 \\
\hline Tabonji & & -374.41 \\
\hline Ilwayab & & -691.43 \\
\hline Okaba & & -393.20 \\
\hline Tubang & & -190.22 \\
\hline Ngguti & & -252.46 \\
\hline Kaptel & & -178.57 \\
\hline Kurik & $47,376.15$ & \\
\hline Animha & & -88.68 \\
\hline Malind & $24,462.71$ & \\
\hline Merauke & & $-5,770.29$ \\
\hline Naukenjerai & $1,397.42$ & \\
\hline Semangga & $36,597.47$ & \\
\hline Tanah Miring & $58,866.46$ & \\
\hline Jagebob & $3,277.53$ & \\
\hline Sota & & -336.31 \\
\hline Muting & & -516.85 \\
\hline Elikobel & 649.70 & \\
\hline Ulilin & 246.06 & \\
\hline Amount & $172,873.50$ & $-9,144.54$ \\
\hline
\end{tabular}

From the results of table 1, it can be concluded that Merauke Regency has a surplus of 171,361.50 tons. Kurik District is the second surplus area after Tanah Miring District which supports Merauke Regency as a rice surplus area. The total surplus in Kurik District reached 47,376.15 tons or $27.41 \%$ of the total district surplus. The acknowledgements should be typed in 9-point Times, without title.

\subsection{The condition of the road in Jaya Makmur Village, Kurik District}

The problem of road infrastructure is still a big task for the Merauke Regency Government (Pemkab) because from the results of existing measurements it is known that only 28.43 percent of paved roads or $1.76 \mathrm{~km}$ of total road length of $6.19 \mathrm{~km}$ can be seen in full in Figure 3. 


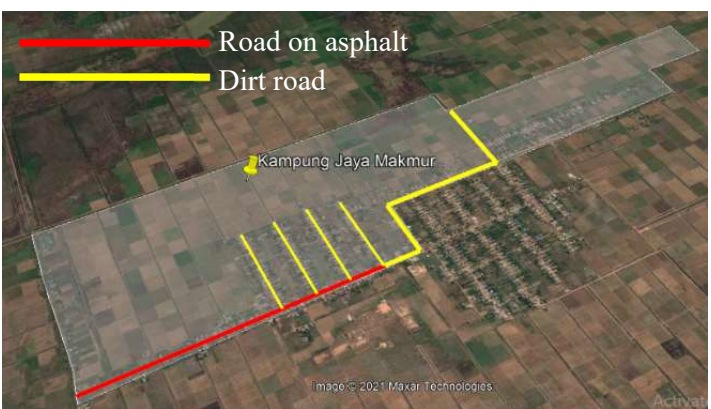

Fig. 3. The road surface of Jaya Makmur Village

The roads in Jaya Makmur Village are divided into 2 types of roads, namely local roads and neighborhood roads. The local road is also called the village axis road and has a length of $3.76 \mathrm{~km}$ with a condition that 1.76 $\mathrm{km}$ is a road with an asphalt surface and $2 \mathrm{~km}$ is a dirt road. Meanwhile, environmental roads have a total length of $2.43 \mathrm{~km}$ with road surface conditions that do not yet have pavement or are dirt roads, which can be seen in full in Figure 4.

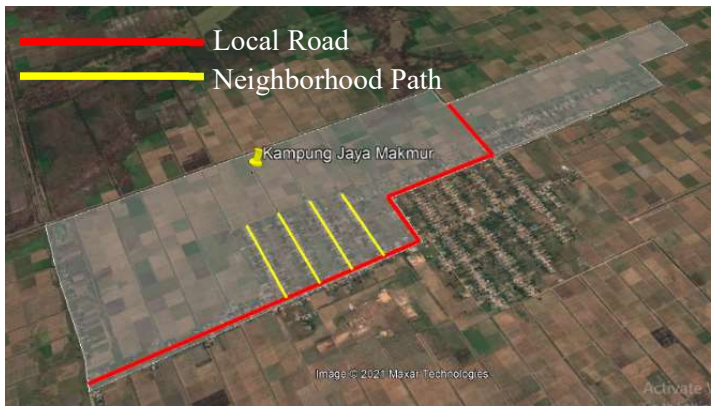

Fig. 4. The figure of the road classification of Jaya Makmur Village

In addition to local roads or main roads in Jaya Makmur Village, there are also environmental roads which are divided into 4 roads, namely Flamboyan Street $0.57 \mathrm{~km}$, Melati Street $0.62 \mathrm{~km}$, Cempaka Street $0.62 \mathrm{~km}$, Mawar Street $0.62 \mathrm{~km}$. which can be seen in full in Figure 5.

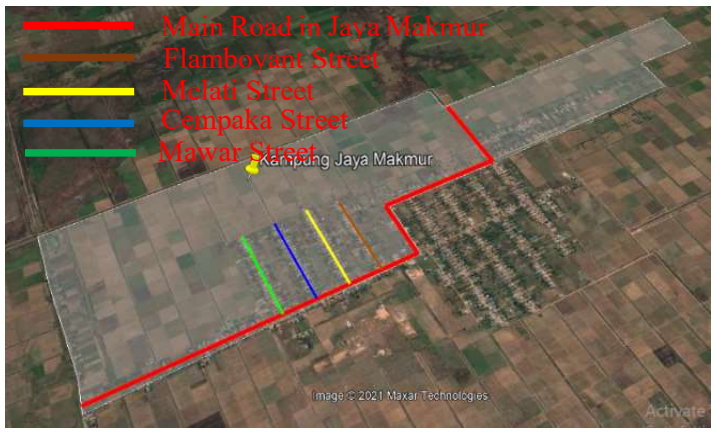

Fig. 5. The name of the street in Jaya Makmur Village

\subsection{Comparing road satisfaction levels and road network performance}

One of the strategies for the embodiment of the national food storage process can be seen from the government's performance achievements in road infrastructure development. To see this achievement, a comparison is made between the performance of the road network and the expectations of the community. The method that can be used is the Importance Performance Analysis (IPA) method, which assesses the factors that are relevant to the choice to be observed and a gap has been found between road performance and the level of community satisfaction with the development of the Jaya Makmur Village road network infrastructure as shown in Figure 6.

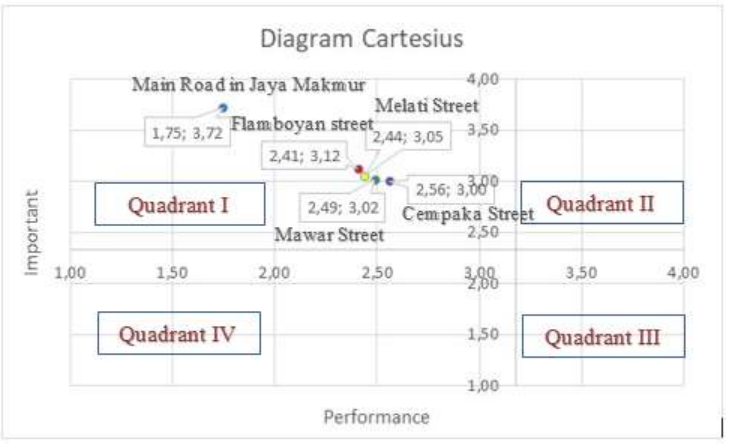

Fig. 6. Diagram of the satisfaction level of road performance and community expectations

The results of the analysis of 40 samples consisting of operators (truck drivers, pick-up drivers, private car/ public transport, and motorbike drivers), users (organda, consultants, contractors, and academics), and the public (community/ farmers) assess the existing road infrastructure. in Jaya Makmur Village, it is in Quadrant I, which means that it needs performance development. There is a gap between low road performance and community expectations of a more viable road. All roads in the Jaya Makmur village have poor road performance or low performance compared to the high expectations of the community for roads that are more feasible or of high importance.

\subsection{Determination of road construction priorities}

The AHP method can be used to determine the priority of road development, namely by using a questionnaire with a hierarchy 1 and 2 hierarchy plan chart. Vector Eigenvalues were obtained after normalization tests and data consistency tests.

In hierarchy 1 it can be explained that the higher the benefit value of the road section, the greater the Eigenvector value. In Jaya Makmur road Village, the Delivery criterion is the most dominant because it relates to smooth mobilization. This is also because the distance between Jaya Makmur Village and the center of Merauke City is relatively far, which is $76 \mathrm{~km}$ and the most important sub-criteria for the people of Jaya Makmur village in road development are Smooth and Fast. 
Table 2. Eigenvector values in order of priority (Hierarchy 1)

\begin{tabular}{|ll|ll|}
\hline Criteria & \multicolumn{2}{|c|}{ Sub Criteria } \\
\hline \multirow{4}{*}{ Delivery } & \multirow{4}{*}{0.47} & Smooth and fast & 0.45 \\
\cline { 3 - 4 } & & On-time & 0.25 \\
\cline { 3 - 3 } & & Easy to reach & 0.20 \\
\cline { 3 - 3 } Quality & \multirow{4}{*}{0.34} & Regular & 0.10 \\
\cline { 3 - 3 } & & Congratulations & 0.34 \\
\cline { 3 - 3 } & & Comfortable & 0.27 \\
\cline { 3 - 3 } & Secure & 0.19 \\
\cline { 3 - 3 } & Orderly & 0.11 \\
\cline { 3 - 3 } & Low Pollution & 0.09 \\
\hline \multirow{4}{*}{0.19} & Efficient & 0.35 \\
\cline { 3 - 3 } & Accessibility & 0.22 \\
\cline { 3 - 3 } & Integrated & 0.19 \\
\cline { 3 - 3 } & Capacity & 0.13 \\
\cline { 3 - 4 } & Rates & 0.11 \\
\hline
\end{tabular}

In hierarchy 2 it can be explained that the higher the Eigenvector value, the greater the desire of the community to develop the road because the road is often used for farmer mobilization in planting activities and also the transportation of agricultural products. The following are the priority directions for the development road Jaya Makmur Village.

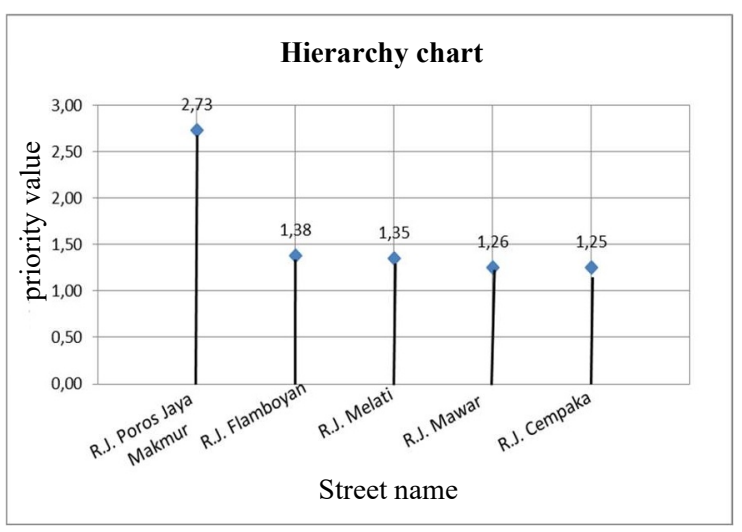

Fig. 7. Eigenvector values in order of priority

The number of eigenvectors with the highest value is found on Main Road in Jaya Makmur with an Eigenvector value of 2.73. Next is Flamboyan Street with a value of 1.38 and Melati Street with a value of 1.35. In addition, the lowest Eigenvector value is Mawar Street with a value of 1.26 and Cempaka Street 1.25. This shows that the community wants the development of the Main Road in Jaya Makmur section so that the mobilization of farmers can be smooth and fast. The section of Main Road in Jaya Makmur that can be developed with unpaved conditions is $2 \mathrm{~km}$ which can be seen again in Figure 2.

\section{Conclusion}

There is a gap between road network performance and community expectations. The gap is in quadrant I, namely the need for performance development. The priority for the development of the Village Jaya Makmur road to support the Kurik District as a rice surplus area is the Main Road in Jaya Makmur section with $2 \mathrm{~km}$ of unpaved conditions. This section is considered to support the delivery or agricultural mobilization to make it smooth and fast.

\section{References}

1. BPS Kabupaten Merauke, Merauke Dalam Angka 2020. Merauke: BPS Kabupaten Merauke, 2020.

2. M. Akbar, C. Utary, Y. Kakerissa, and S. Asmal, "Analysis of the Effect of Parking on Road Bodies on Road Service Levels," IOP Conf. Ser. Earth Environ. Sci., vol. 343, no. 1, 2020, doi: 10.1088/1755-1315/343/1/012185.

3. M. Akbar, M. Yamin Jinca, and J. Rahim, "Combination of the IPA-SWOT-AHP Models For the Formulation of the Road Network of Development Policy (A Case Study in Merauke Regency, Papua Indonesia)," Int. J. Eng. Technol. IJET-IJENS, vol. 18, no. 03, pp. 183403-5757, (2018).

4. BPS Kabupaten Merauke, Merauke Dalam Angka 2016. Merauke: BPS Kabupaten Merauke, 2016.

5. Sri. Junarty et al, "Stakeholder Knowladge of Sustainable Road Implementation In Buru Regency," Int. J. Mech. Civ. Eng., vol. 15 (2), no. 2, pp. 38-42, (2018), doi: 10.9790/16841502013842

6. M. Akbar, C. Utary, and Y. H. Rada, "Redesign Runway Strip with Evaluate the Geometry, Cut and Fill-In, and CBR at Mopah Airport," J. Phys. Conf. Ser., vol. 1569, no. 4, (2020), doi: 10.1088/1742-6596/1569/4/042036.

7. M. Akbar, E. Budianto, and B. Doloksaribu, "Penentuan Besarnya Tarif Angkutan Dalam Kota ( Angkot ) Dengan Metode BOK," Musamus J. Civ. Eng., vol. 1, no. 2, pp. 12-15, (2019), doi: https://doi.org/10.35724/mjce.v1i2.2037.

8. A. K. Das and P. K. Bhuyan, "Level of Service criteria of urban streets using Clustering Large Application (CLARA)," Adv. Transp. Stud., no. 32, pp. 75-88, (2014).

9. K. T. Geurs, B. van Wee, and P. Rietveld, "Accessibility appraisal of integrated land-usetransport strategies: Methodology and case study for the Netherlands Randstad area," Environ. Plan. B Plan. Des., vol. 33, no. 5, pp. 639-660, (2006), doi: $10.1068 / \mathrm{b} 31099$.

10. S. Karou and A. Hull, "Accessibility modelling: Predicting the impact of planned transport infrastructure on accessibility patterns in Edinburgh, UK," J. Transp. Geogr., vol. 35, pp. 111, (2014), doi: 10.1016/j.jtrangeo.2014.01.002.

11. D. N. Tiwari, R. Loof, and G. N. Paudyal, "Environmental-economic decision-making in lowland irrigated agriculture using multi-criteria analysis techniques," Agric. Syst., vol. 60, no. 2, pp. 99-112, (1999), doi: 10.1016/S0308521X(99)00021-9. 
12. P. Jankowski, "Integrating geographical information systems and multiple criteria decisionmaking methods," Int. J. Geogr. Inf. Syst., vol. 9, no. 3, pp. 251-273, (1995), doi: 10.1080/02693799508902036.

13. F. Wang, G. Brent Hall, and Subaryono, "Fuzzy information representation and processing in conventional GIS software: Database design and application," Int. J. Geogr. Inf. Syst., vol. 4, no. 3, pp. 261-283, (1990), doi: 10.1080/02693799008941546.

14. J. Dj, M. Yamin Jinca, and M. S. Pallu, "The Development of Sub Terminal Agribusiness Sumillan As A Transaction Center of Agribusiness Results in Enrekang Regency, South Sulawesi Indonesia," Int. Ref. J. Eng. Sci. ISSN, vol. 6, no. 10, pp. 2319-183, (2017). 